\title{
Effects of wildfires on flora, fauna and physico-chemical properties of soil-An overview
}

\author{
Manoj Kumar Jhariya* and Abhishek Raj ${ }^{1}$ \\ Department of Farm Forestry, Sarguja University, Ambikapur- 497001 (C.G.), INDIA \\ ${ }^{1}$ Department of Forestry, College of Agriculture, Indira Gandhi Krishi Viswavidyalaya, Raipur- 492012 (C.G.), INDIA \\ *Corresponding author. E-mail: manu9589@gmail.com
}

Received: May 06, 2014; Revised received: October 15, 2014; Accepted: December 09, 2014

\begin{abstract}
Fire is one of the most destructive threats faced by our forests. Fire is good servant but a bad master. The fire season starts in March/April continues up to June. Wildfires destroy not only flora (tree, herbs, grassland, forbs, etc.) and their diversity but also considerable long term negative impact on fauna including wild endangered species. Repeated fires can convert some shrub-lands to grass and fire exclusion converts some grassland to shrub-land and forest. Fires affect animals mainly through effects on their habitat. The extent of fire effects on animal communities generally depends on the extent of change in habitat structure and species composition caused by fire. Fire can also influence a physico-chemical property of soil including texture, color, bulk density, pH, porosity, organic matter, nutrient availability and soil biota. Drought, disease, insect infestation, overgrazing or a combination of these factors may increase the impact of fire on an individual plant species or communities. Common effects include plant mortality, increase flowering, seed production and numerous communal affects. Fire affected area showed reduction in species diversity both in flora and fauna. In a social context, fire directly affects people, property and infrastructure, thereby directly affecting the health and livelihood of individuals and communities.
\end{abstract}

Keywords: Diversity, Flora, Fauna, Habitat, Wildfires

\section{INTRODUCTION}

Forest fires are considered to be a potential hazard with physical, biological, ecological and environmental consequences (Jaiswal et al., 2002). Majority of wildfires are initiated by nature as well as by man itself. People cause fires accounts $98 \%$ of the all fires, while natural factors are responsible for the remaining $2 \%$. Of the people caused fires $23 \%$ was classified as arson, $27 \%$ as negligence and carelessness and $50 \%$ as unknown (Neyisci, 1985; Mol and Kucukosmanoglu, 1997; Mustafa, 2009). A total of 8,645 forest fire incidences have been reported during 2004-2005; 20,567 during 2005-2006; 16,779 during 2006-2007; 17,264 during 2007-2008; 26,180 during 2008-2009; 30,892 during 2009-2010 and 13,898 during 2010-2011, respectively in India. Central India including Madhya Pradesh is highly prone to forest fire followed by state likes Maharashtra, Chhattisgarh and Odisha (FSI, 2012). Fire can change plant composition, structure, diversity (Jhariya, 2011; Jhariya et al., 2012; Jhariya, 2013; Kittur et al., 2014a $\&$ b), destroy biomass, organic matter and influence the physical and chemical properties of soil including the loss or reduction of structure and soil organic matter, reduced porosity and increased $\mathrm{pH}$ (DeBano, 1990; Certini, 2005; Jhariya, 2014; Jhariya et al.,
2014). As per Raj and Jhariya (2014) fire is a big disaster in the forest causes a loss of natural resources, depleting of soil biomass resulting loss of various mobile nutrient. Impact of forest fire is varies from vegetational structure of forest community, availability of fuel load, frequency, intensity and fire return interval of that forest. Globally, biomass fires are burning between 3-4.5 million $\mathrm{Km}^{2}$ per year, this is area equivalent to India plus Pakistan or more than half of Australia (Chatenoux and Peduzzi, 2012). However, impacts from biomass fires are numerous and severe. They include loss of soil cohesion from heat, which then accelerate soil erosion (from wind or rain), it destroys complex ecosystems and thus has a significant impact on biodiversity, it emits GHG, and biomass fires are responsible for $17.4 \%$ of $\mathrm{GHG}$ global emissions (Solomon et al., 2007). Fire encouraged fire-tolerant tree species and discouraged fire-sensitive species as reported by Ivanauskas et al. (2003). Fires may also play a significant role in regulating ecosystem productivity and diversity by promoting mineralization of nutrients stored in organic matter and allowing the invasion of rapid growing early successional species (Busse et al., 1996; DeBano et al., 1998; Boerner et al., 2009). Soil provides numerous essential ecosystem services such as primary production (including agricultural and forestry 
products); regulation of biogeochemical cycle (with consequences of the climate); water filtration, resistance to diseases and pests and regulation of above ground biodiversity (Jhariya and Raj, 2014). Fire leads to important change in physical, chemical and biological properties of soil, which are relevant for the future productivity and sustainability of ecosystem (Neary et al., 2005). Wang et al. (2012) reported that fire increases $\mathrm{C}$ and $\mathrm{N}$ availability and increase microbial activity, which consequently decreases the potential rates of $\mathrm{C}$ sequestration. The extent and duration of these effects on soil properties depend on the intensity and residence time, fire severity (Certini, 2005). Large and damaging wildfires have occurred in Australia (Bradstock et al., 2009), Canada (Wang et al., 2010), China (Casanova et al., 2008), throughout the Mediterranean basin (Leone et al., 2009), Siberia (Achard et al., 2008), Southeast Asia (Khandekar et al., 2000) and the United States, particularly in Alaska, the southeast and west (Littell et al., 2009). Fires effect is generally depends upon the presence of fire hazard materials i.e. accumulation of fuels, moisture content and ignition incidence. Fuel accumulation is generally depends on the production and decomposition of ignitable material, which varies among the vegetation and forest types. Kittur and Jhariya (2012) reported that duffs litter and wood litter in both high fire and medium fire zones in the post-fire season was decreased. While in low fire and non-fire zones the fuel load was increased due to protection from fire in moist deciduous forest of Achanakmar-Amarkantak Biosphere Reserve. Fire influence nutrients status of soil by burning of organic matter. While making fire line and fuel-breaks are most remarkable method for fire-suppression in several forests. But some research indicates that fire has been part of Indian ecosystems for several millennia and that fire prevention has lead to the proliferation of invasive species, which ironically has increased the fire frequency in ecosystems (Hiremath and Sundaram, 2005). The purpose of this paper is to review the effect of wildfire on flora, fauna and various property of soil, which are important in maintaining healthy ecosystem.

\section{EFFECTS OF WILDLIFE ON FLORA}

Fire damages the tree, shrubs and plants. Globally, more than $350 \mathrm{~m}$ ha of forests was burned in 2000, equal to $6 \%$ of the world's geographical area (FAO, 2007). The extent of damage depends on the species, age, intensity of fire and vegetation types.

\section{EFFECTS ON FORESTS}

Fire enter forests through in-cendiarism and accidental fires (Kodandapani et al., 2008) and introduced by various indigenous communities to aid in the collection of non-timber forest products (Narendran et al., 2001; Saha, 2002). The extent of damage and response of tree to fire is depends upon the fire parameter including intensity, severity, soil heating, season of burn, residence time and time since last fire. In addition, numerous physical and climatic factors (e.g., fuel condition, weather, slope, and aspect) as well as biological factors (plant morphology and physiology) also influence post-fire effects on plant communities. Indian forests are broadly classified into 16 types (Champion and Seth, 1968). Of these, large area of tropical deciduous forests is under intense pressure due to recurrent fires. Of the six vegetation types, dry deciduous forest shows significantly high burnt area, followed by thorn forest, broadleaved forest, dry savannah, Scrub and grasslands (Krishna and Reddy, 2012). Seasonally dry tropical forests are considered to be the most threatened from natural fires, land use change and escaped fires following slash and burn agriculture during the dry season (Murphy and Lugo, 1986a; Kauffman et al., 2003). Fire is also effect on biomass and carbon accumulation by directly reduce biomass and carbon stored in seasonally dry tropical forests (Kauffman et al., 2003; Van der Werf et al., 2003). As per Jhariya et al. (2014) forest fire have significant impact on biomass and carbon storage pattern on tree species while the shrubs produce higher biomass in the area where fire is more common or high severity as compare to protected site due to reduction of competition due to open canopy in tropical dry deciduous forest.

According to Vargas et al. (2008), carbon stored in belowground fractions could rapidly be lost if forests are disturbed and the thin soil is lost by fire or erosion with a potential carbon loss between 120 and $150 \mathrm{Mg}$ $\mathrm{Cha}^{-1}$ in a mature forest. In addition, fires smoke has direct impact on the surface energy budget and increase atmospheric temperatures (Wang and Christopher, 2006) and produce feedbacks on the evaporation processes, cloud formation and precipitation patterns that could affect the hydrologic cycle at regional scales (Menon et al., 2002; Allen and Rincon, 2003). Fire also influences the pattern of litter-fall and nutrient input in forest. Dezzeo and Chacon (2006) have worked on effects of fire on litter-fall and nutrient input in forests of Gran Sabana, Southern Venezuela and reported that total annual litter-fall was $5.19 \mathrm{Mg} \mathrm{ha}^{-1}$ year $^{-1}$ in the tall forest (tall primary forest), $5.65 \mathrm{Mg} \mathrm{ha}^{-1}$ year $^{-1}$ in the medium forest (slight fire affected forest) and $3.93 \mathrm{Mg} \mathrm{ha}^{-1}$ year ${ }^{-1}$ in low forest (strong fire affected forest). Result shows that annual litter-fall values of the tall and medium forests did not differ significantly between them, but were significantly higher than the annual litter-fall value for the low forest. Also between tall and medium forests, the annual input of nutrients was similar with the exception of $\mathrm{Ca}$, which was significantly higher in tall forest and low forest showed significantly lower annual inputs of $\mathrm{N}$ and $\mathrm{P}$, and a significantly higher input of $\mathrm{K}$, in compared tall and medium forests. Broad leaved species are more vulnerable than the conifers due to corky bark. Resin 
tapped tree are severally affected by fire than the non-tapped trees.

According to Chandra (2005), high resin content in sub-tropical pine region and dry condition in the tropical region have been a major cause of fire spreads in India. Fire also influences the richness and diversity of tree seedling species (Jhariya and Oraon, 2012a) and it may causes killing of both root-crown re-sprouters and root -sprouters. The decline of species richness in time after forest fire might be caused primarily by the elimination of some early species which were over topped and shaded out by rapidly growing fire hardy species. In high fire zones more than $44 \%$ seedling population decreased after fire season, it will adversely affect the forest stratification in future. Fires have negative impacts on native plant diversity, with varying effects on species and ecosystems including the potential for localized extinction (Kittur et al., 2014b). Fire has positive effect on the plant diversity in the Oak forest (Bakhtar et al., 2013). Saha and Howe (2003) reported that, diversity was also significantly higher among seedlings in the fire-excluded plots than the burned plots, amounting to a $28 \%$ reduction in diversity in tropical dry forest in Mendha Forest of central India. Characters including thick bark, fire-stimulated sprouting, germination or seed dispersal, resistance to rotting, modified seedling structure and thick heat-resistant buds, which show fire tolerating capacity of the tree species (Myers, 1990; Abrams, 1992; Bond and Van Wilgen, 1996; Wade et al., 2000).

Lodgepole pine has a hard coated seeds or serotinous cone, open to release seed in the presence of heat of fire. In India, about thousand hectares of forests of south western Himalayan region (Uttarakhand) are burned every year by the forest fires. The vulnerability of the Indian forests to fire varies from place to place depending upon the type of vegetation, climate and season of fire. The coniferous forest in the Himalayan region comprising of fir (Abies spp.), spruce (Picea smithiana), Cedrus deodara, Pinus roxburghii and Pinus wallichiana etc. is very prone to fire. Various regions of the country have different normal and peak fire seasons, which normally vary from January to June. In the plains of northern and central India, most of the forest fires occur between February and June. In the hills of northern India fire season starts later and most of the fires are reported between April and June. In the southern part of the country, fire season extends from January to May. In the Himalayan region, fires are common in May and June (IFFN, 2002). Physiographic factors, i.e. elevation and slope aspect across different forest types is also influence the extent of fire. Joshi $e t$ al. (2013) studied on effects of fire in relation to aspects on number of seedling, sapling and biomass stock in Oak and Pine mixed forests of Kumaun central Himalayas, India. They reported that those studied sites where fire frequency was regular (every year) the number of sapling and seedling count was 360 individual ha ${ }^{-1}$ and 370 individual ha ${ }^{-1}$ in south-eastern aspect, while this number increased to 610 and 370 individual $\mathrm{ha}^{-1}$ for the north-western aspect where fire occurred once in a five year. The forest tree biomass and carbon also decreased in south-western aspects $\left(9.47 \mathrm{tha}^{-1}\right.$ and $\left.38.54 \mathrm{t} \mathrm{ha}^{-1}\right)$ than north-western site $\left(62.54 \mathrm{t} \mathrm{ha}^{-1}\right.$ and $\left.49.93 \mathrm{t} \mathrm{ha}^{-1}\right)$, where fire frequency is every year. On southern aspects of pine forests in Garhwal Himalaya, frequent fires are common. This is due to the high inflammability of igniting material due to a low water content and high surrounding temperature. Moreover, the forests growing on the southern aspects are generally exposed to harsh climatic conditions and are prone to various natural disturbances like wind fall, wild fire, etc., which hinder accumulation of large amount of biomass on these aspects (Sharma et al., 2011).

According to Jhariya (2014) fire have negative impact on carbon storage, carbon stock, net production and potential C sequestration in a seasonally dry forest ecosystem. Site productivity is also influence by the consequence of wildfire. Productivity is maintained by the presence of essential nutrients including N, S, P, K, Ca etc, which can be altered by fire. Klock and Grier (1979) reported that detrimental effects of fire on the long term site productivity may be greater in forest regions lacking significant vegetative $\mathrm{N}$-fixation. Also fire can reduce Nitrogen status, which results in lower net primary productivity (NPP) and carbon storage. Thornley and Cannell (2004) reported that loss of carbon on combustion of about $500 \mathrm{~kg} \mathrm{C} \mathrm{ha}^{-1}$ year $^{-1}$ represented about $17 \%$ of the NPP (3000 kg C ha ${ }^{-1}$ year $\left.^{-1}\right)$ in Boreal forest. Rocha et al. (2013) reported that total NPP for control plot was higher $\left(10.36 \pm 0.64 \mathrm{Mg} \mathrm{C}^{-1} \mathrm{year}^{-1}\right)$ than burn plot $\left(8.80 \pm 0.62 \mathrm{Mg} \mathrm{C}^{-1}\right.$ year $\left.^{-1}\right)$ in dry southern limit of Amazon rainforest (Brazil). Forest biomass burning is also influence emission of $\mathrm{CO}_{2}$ in environment, which causes greenhouse effects. Tropical deforestation provides a significant contribution to anthropogenic increases in atmospheric $\mathrm{CO}_{2}$ concentration that may lead to global warming. So, forest plays a lead role for maintaining the $\mathrm{CO}_{2}$ level, $\mathrm{C}$ sequestration and protects the ecosystem from global warming. Badarinath and Vadrevu (2011) reported that, $2,414 \mathrm{Km}^{2}$ area has been estimated to be burnt annually in forested area including closed broad-leaf deciduous forest, closed needle-leaf evergreen forest, closed to open broad-leaf evergreen/semi-deciduous forest, closed/open mixed broadleaf/needle-leaf forest, mosaic forest/grassland/shrub-land and open broad-leaf deciduous forest in India. The $\mathrm{CO}_{2}$ emissions averaged across seven years were $\sim 6.34 \mathrm{CO}_{2} \mathrm{Tg} / \mathrm{yr}$ from biomass burning of these forest types. Susceptibility and vulnerability to wildfire is also depends on type of forest. As per report of IFFN (2002) maximum frequent fire (50\%) was reported in north-eastern region as compared to minimum (5\%) in Dry deciduous. Also, maximum occasional fire $(60 \%)$ was reported in Moist deciduous forest in comparison 
to lowest $(35 \%)$ in Dry deciduous forest. It was shown in Table 1.

\section{EFFECTS ON SHRUBS}

Morphological characteristics including crown size and shape, height, branch density, ratio of live to dead crown material, crown base location with respect to surface fuels and total crown size are determine a shrubs vulnerability to fire. In general small buds and branches, due to their small mass and high surface area to volume ratios, are more susceptible to lethal heating than large buds. Bark thickness, composition, cracks and moisture content is also determining the protecting quality of bark and fire impacts on shrubs stem. Fire can also cause root mortality. According to Sheuyange et al. (2005), frequent fires reduced shrub cover temporarily and promoted herbaceous cover. However, the frequent fires positively influenced the herbaceous and tree species. When canopy disturbance and surface fires occur in tandem or relatively close together in time, the increase in light can contribute to the development of a recalcitrant understory layer (Mallik, 2003, Payette and Delwaide, 2003). Jhariya and Oraon (2012c) censured lianas and shrubs in four sites (High, medium, low and non-fire zone) of tropical forest ecosystem of Chhattisgarh, reported that density of lianas and shrubs was varied from 1120 to 2480 individuals $\mathrm{ha}^{-1}$ during pre-fire season and 1920 to 3360 individuals $\mathrm{ha}^{-1}$ at the time of post-fire season. The total 11 species were recorded during pre-fire season whereas it had increase after the fire (20 species). The forest fire in addition to the intermittent canopy structure provides favorable habitats for the development and high abundance.

The potential of lianas and shrubs to regenerate well naturally where the fire events and/or higher anthropogenic disturbances are common (Rodgers et al., 1986; Kumar and Thakur, 2008; Sahu et al., 2008; Mishra et al., 2008; Jhariya and Oraon, 2012c). Various reasons are reported by different workers which supports to lianas and shrubs growth like fire derived nutrient deposition (Asner et al., 1997; Dawson et al., 2002; Chen et al., 2010; Jhariya, 2010), availability of tree-fall gaps resulted from the natural and/or anthropogenic disturbance (Putz, 1983; Laurance et

Table 1. Susceptibility and vulnerability of Indian forests to wildfire (IFFN, 2002).

\begin{tabular}{lcc}
\hline Type of forest & $\begin{array}{c}\text { Fire } \\
\text { frequent } \\
(\boldsymbol{\%})\end{array}$ & $\begin{array}{c}\text { Fire } \\
\text { occasional } \\
(\boldsymbol{\%})\end{array}$ \\
\hline Coniferous & 8 & 40 \\
Moist Deciduous & 15 & 60 \\
Dry Deciduous & 5 & 35 \\
Wet/Semi-Evergreen & 9 & 40 \\
North-Eastern Region & 50 & 45 \\
\hline
\end{tabular}

al., 2001; Schnitzer and Bongers, 2002; Schnitzer and Bongers, 2011; Schnitzer et al., 2012), there may be less competition due to open canopy (Perez-Salicrup et al., 2001; Gianoli et al., 2010; Schnitzer et al., 2012) because fire causing damage to sensitive species which resulted killing of the trees and new growing ones (Jhariya, 2013). The decline of species after forest fire might cause elimination of some early species which were over topped and shaded out by rapidly growing woody plants, especially resprouters (Miller, 2000).

\section{EFFECTS ON GROUND VEGETATION}

Burning alone can result in increased forbs abundance (Wienk et al., 2004) graminoid abundance and under story species richness (Busse et al., 2000; Laughlin et $a l .$, 2004). Both Herbivores and fire frequency together drive forest-grassland dynamics in savannas (Holdo et al., 2009). The herbs number, density, diversity increase after fire because of reduction in number of tree species and permit more to more light in the ground floor. Jhariya and Oraon (2012b) studied the impact of forest fire on herbaceous vegetation of four sites (High, medium, low and non-fire zone) in Bhoramdeo Wildlife Sanctuary situated in Chhattisgarh, India and reported that fire cause increased in species number (19) and density during pre-fire (112000 to $668000 \mathrm{ha}^{-1}$ ) and species number (30) and density ( 230000 to $510000 \mathrm{ha}^{-1}$ ) during post fire season. Also the herb layer showed higher density after post-fire in high and low fire zones, whereas decreased in medium fire zone due to change in season, the density of herb layer also increased $(40.03 \%)$ after post-fire in non-fire zone. The areas or sites facing forest fire or other biotic disturbances supports more herbaceous vegetation as compared to undisturbed one due to the lower competition for various resources (Jhariya and Oraon, 2012b; Jhariya et al., 2013). The herbaceous vegetation increase after fire events because of general reduction in tree cover that brings more sunlight to the soil and for growing understorey or herbaceous cover (Moretti et al., 2002; Sheuyange et al., 2005; Keith et al., 2010). Azizi et al. (2006) also stated that the fire mainly affects the undergrowth vegetation, and highest species diversity in moderately disturb ecosystem than in undisturbed ecosystems (Connell, 1978; Decocq et al., 2004).

\section{EFFECTS ON WILD ANIMALS}

Fire has influenced composition, structure and landscape patterns of animal habitat. Wildlife may be affected by fire both through direct mortality or habitat alteration (Lyon et al., 2000b). Some fires alter the vegetation structure of forest, which is work as shelter and hiding cover for wild-animals and vegetation structure spatially arranged all the resource needed to live and reproduce. Dead wood on the ground is an essential habitat component for many birds, small mammals and even large mammals, including bears 
(Bull and Blumton, 1999). Fire cause large dead logs on the ground, harbor many invertebrates and are particularly of ants; they also provide shelter and cover for small mammals, amphibians and reptiles. Ground-nesting birds could be killed prior to fledging (Reinking, 2005) and forest floor arthropods in the egg or larval stages may be more vulnerable to loss (Niwa and Peck, 2002). Dark-eyed juncos (Junco hyemalis) often choose nest sites in unburned patches within prescribed fire units (Sperry et al., 2008). Amphibians are also likely to be more active with the moister conditions under which prescribed fires are typically conducted (Pilliod et al., 2003). The longer term responses of many bird species are thought to be due primarily to structural changes of vegetation or changes to food resources, as affected by fire severity (Huff and Smith, 2000; Kirkpatrick et al., 2006).

\section{EFFECTS ON SOIL PROPERTY}

Fire can influence physical and chemical properties of soil.

Effects on physical properties of soil: Soil physical properties are those characteristics, process, or reactions of a soil that are caused by physical forces that can be described by, or expressed in, physical terms or equations (SSSA, 2001). It can increase the soil pH (Aref et al., 2011), however significant increase occurs only at higher temperature and fire can also cause increase in bulk-density of soil because of collapse of aggregate and clogging of voids by the ash and dispersed clay minerals; as a consequence, soil porosity and permeability decreases (Certini, 2005). Jhariya (2014) stated that forest fire have a significant impact of soil physical properties like texture, bulk density, moisture regime etc. Fire can also influence the soil water repellency (WR). High surface temperature 'burn' off organic materials and create vapours that move downward in response to a temperature gradient and then condense on soil particles causing them to become water repellent (Letey, 2001). As a result of increased hydrophobicity (water repellency), infiltration rate to be decreases and increased runoff that often results in increased erosion (DeBano, 2000). Ekinci (2006) reported that wildfire can increased soil $\mathrm{pH}$, electrical conductivity (EC), available $\mathrm{P}$ and $\mathrm{K}$, organic $\mathrm{N}$ content; reduced CEC, porosity, urease activity, total organic carbon (TOC) and soil water content. But Aref et al. (2011) reported that electrical conductivity (+/-) significantly decreased from 2.13 in unburned sites to $1.1 \mathrm{dS} \mathrm{m}^{-1}$ in burned sites in Al Hilia Forest (Saudi Arabia). The component of soil texture $(+/-)$ is also affected by nature and duration of fire. Nardoto and Bustamante (2003) reported that percentage of sand, silt and clay varied from burned to unburned site at the depth of $0-5 \mathrm{~cm}$ in Cerrado Stricto sensu sites. According to him, except of clay\%, percentage of sand and silt are increased from unburned site $(15 \%, 11 \%)$ to burned site $(21 \%, 13 \%)$ respectively but the value of clay decreased from unburned site $(74 \%)$ to burned site $(66 \%)$. Also reported that bulk density increased from 0.64 to $0.67 \mathrm{gcm}^{-3}$ and per cent of total porosity decreased from 76.0 to 75.6. Aref et al. (2011) reported that fire did not affects soil texture and this was indicated by the fact that sand, silt and clay (\%) were not significantly different when burned locations were compared with normal ones in Al Hilia Forest (Saudi Arabia).

Effects on chemical properties of soil: Forest fire can influence the availability of organic carbon and soil nutrient dynamics (Jhariya, 2014). Globally, forests are the most important carbon pool in terrestrial ecosystems (Dixon et al., 1994), containing 66-80\% of all carbon stored in above-ground biomass and $45 \%$ of that found in below-ground terrestrial pools (Dixon and Turner, 1991; Waring and Running, 1998). Soil organic matter (SOM) represents the third largest terrestrial carbon pool, with a global estimated total of $1526 \mathrm{PgC}$ (Lal, 2004). Total and partial destruction of soil organic matter is generally depending on fire severity, intensity, dryness of the surface organic matter (OM) and fire type and other factors like soil moisture, soil type and nature of burned materials. Nabatte and Nyombi (2013), reported that mean soil organic matter content in the burnt plots was lower (4.593\%, range $2.6-6.1 \%$ ) than that of the unburned plots $(5.11 \%$, range $2.8-8.2 \%)$, implying that burning decrease the organic matter content. Low intensity prescribed fire usually results in little change in soil carbon, but intense prescribed fire or wildfire can result in a huge loss of soil carbon (Johnson, 1992). Fire effects on organic carbon (+/-) of mineral soil range from no effect (Johnson and Curtis, 2001; Certini, 2005) to a loss of $60 \%$ (Bormann et al., 2008). Nutrient status (+/-) of soil is also influence by occurrence of fire. Effects of fires on soil organic $C$ and total $\mathrm{N}$ was highly variable and controversial. Some studies demonstrated that fires significantly decreased soil organic $\mathrm{C}$ or total $\mathrm{N}$ (Mabuhay et al., 2003; Zhang et al., 2005; Nabatte and Nyombi, 2013), increase (Boerner et al., 2004) and neutral effect or little effect of fire (Wilson et al., 2002; Knoepp et al., 2004). Also burn soil has low mean phosphorus content (5.77 $\mathrm{mg} \mathrm{Kg}^{-1}$, range 1.1-29.6 $\mathrm{mg} \mathrm{Kg}^{-1}$ ) than un-burnt plots $\left(6.34 \mathrm{mg} \mathrm{Kg}^{-1}\right.$, range $1.2-39.2 \mathrm{mg} \mathrm{Kg}^{-1}$ ) (Nabatte and Nyombi, 2013) and remains unchanged (Neff et al., 2005). Ammonium $\left(\mathrm{NH}_{4}{ }^{+}\right)$and nitrate $\left(\mathrm{NO}_{3}^{-}\right)$are the inorganic forms of nitrogen that originate during the burning (Certini, 2005). Because of high temperature, soil macro-nutrients (+/-) are loss through volatilization as a result of wildfire. The behavior of micronutrients, such as $\mathrm{Fe}, \mathrm{Mn}, \mathrm{Cu}, \mathrm{Zn}, \mathrm{B}$, and Mo, with respect to fire is not well known because specific studies are lacking (Certini, 2005). Garcia-Marco and Gonzalez-Prieto (2008) has reported that prescribed fire cause short-term changes in the soil micro-nutrient availability, increasing that of $\mathrm{Mn}$ and $\mathrm{Zn}$ and decreasing that of $\mathrm{Fe}$ and $\mathrm{Co}$; they found no 
effect on $\mathrm{Cu}$ availability. The most significant short-term effects of the wildfire are the increases in the soil solution concentrations and /or leaching of mineral forms of $\mathrm{N}, \mathrm{S}$ and $\mathrm{P}$ (Murphy et al., 2006). Wildfire can also influence the $\mathrm{C} / \mathrm{N}$ ratio $(+/-)$ in somewhat extent. Prescribed burning reduced the thickness of the forest floor and caused a low $\mathrm{C} / \mathrm{N}$ ratio (Hogberg et al., 2007). Badia and Marti (2003) reported that $\mathrm{C} / \mathrm{N}$ ratio, soil organic matter content and nutrient availability all increased after burning.

Effects on biological properties of soil: Fire can affects biological organisms including invertebrates and micro-organism (soil bacteria, mycorrhiza) in direct and indirect way. Soil dwelling invertebrates play an important role in litter decomposition, carbon and nutrient mineralization, soil turnover and soil structure formation (Neary et al., 1999). Fire generally affects abundance, species composition, instant mortality and habitat alteration of soil dwelling invertebrates. Soil microbial biomass $(+/-)$ is a potential source of plant nutrients and a higher level of soil microbial biomass is an indicator of soil fertility and soil health. This microbial biomass of soil is defined as the part of the organic matter in the soil that constitutes living smaller microorganisms. The soil microbial biomass carbon (+/-) comprises $1-3 \%$ of total organic carbon in soil (Jenkinson and Ladd, 1981). Fire in tall grass prairie has been found to reduce both SMBC and SMBN (Ajwa et al., 1999) but can be increase SMBC via a long term increase in root production (Ojima et al., 1994; Fynn et al., 2003).

Fire results reduction in micro-organism biomass, which play an important role in nutrient cycling and energy flow in forest ecosystem. Effects of fire on soil microbial biomass may be positive (Mabuhay et al., 2003; Liu et al., 2007), negative (Choromanska and DeLuca, 2001; Rodriguez et al., 2009), or neutral (Rutigliano et al., 2007). Jhariya (2014), found considerable site to site variability in the amount of microbial biomass carbon associated with the soil sampling depth, season and different fire regimes as well. These all the fire sites differed in the quantity and floristic composition of the vegetation. The numbers of tree species affect the availability and biochemical composition of organic matter inputs in soil (Leckie et al., 2004). Changes in soil microbial biomass induced by fire have been noted to be more complex. The forest fire significantly decreased microbial biomass $\mathrm{C}$, which was in agreement with some previous reports (Grady and Hart, 2006; Waldrop and Harden, 2008; Campbell et al., 2008; Rodriguez et al., 2009; Swallow et al., 2009; Sun et al., 2011). Otsuka et al. (2008) reported that community structure of soil bacteria in post-fire non-climax forest several years after fire can be more heterogeneous compared with that in unburned climax forest. Campbell et al. (2008) also reported that burning treatment caused a significant reduction in soil carbon sources and therefore altered the soil microbial community structure.

\section{Conclusion}

Fire is a natural ecological disturbance factor in forest and these forests plays an important role to maintain ecosystem structure and their function and provide services include carbon storage, production of $\mathrm{O}_{2}$, production of biomass (timber, fire wood) and production of pharmaceutical products. Wildfires create a myriad of environmental, social and economic impacts. Wildfire impacts includes total acres burned, cost of fire suppression, damage to homes and structures, alteration of wildlife habitat, damage to watersheds and water supply, damage to public recreation facilities, evacuation of adjacent communities, tourism impacts, damage to timber resources, destruction of cultural and archaeological sites, costs of rehabilitation and restoration, public health impacts, transportation impacts. To save the forest from scourge of fire is thus a central responsibility of forest managers in this country. From conservation point of view, maintaining and sustaining these all forest types is important as they harbor high biodiversity of not only plant species, but are also a preferred habitat for several wild animals. From management perspectives a participatory approach should incorporate for betterment of environmental conservation and ecological stability. Use of controlled fire, fire lines, fuel breaks, fuel load removal and mapping of fire sensitive areas are key principles to minimize fire risk. Remote sensing and GIS is novel techniques for detection and monitoring systems for fire prediction and it must become an integral part of fire management.

\section{REFERENCES}

Abrams, M.D. (1992). Fire and the development of oak forest. Bioscience, 42(5): 346-353.

Achard, E., Eva, H.D., Mollicone, D. and Beuchle, R. (2008). The effect of climate anomalies and human ignition factor on wildfires in Russian boreal forests. Philosophical Transactions of the Royal Society B: Biological Sciences, 363: 2331-2339.

Ajwa, H.A., Dell, J. and Rice, C.W. (1999). Changes in enzyme activities and microbial biomass of tall-grass prairie soil as related to burning and nitrogen fertilization. Soil Biology \& Biochemistry, 31: 769-777.

Allen, M.F. and Rincon, E. (2003). The changing global environment and the lowland Maya: past patterns and current dynamics. In: The lowlands Maya Area: Three Millennia at the Human-Wildland Interface (eds Gomez -Pompa, A, Allen, M.F., Fedick, S.L., Jimenez-Osornio, J.J.), pp. 13-30. Haworth Press, Binghamton, N.Y.

Aref, I.M., Atta, H.A., Ghamade, A.R. (2011). Effects of forest fires on tree diversity and some soil properties. International Journal of Agriculture and Biology, 13: 659-664.

Asner, G.P., Seastedt, T.R. and Townsend, A.R. (1997). The decoupling of terrestrial carbon and nitrogen cycles. Bioscience, 47: 226-234.

Azizi, P., Shafiei, A.B., Akbarinia, M., Jalali, S.G. and 
Hosseini, S.M. (2006). Effect of Fire on Herbal Layer Biodiversity in a Temperate Forest of Northern Iran. Pakistan Journal of Biological Sciences, 9: 2273-2277.

Badarinath, K.V.S. and Vadrevu, K.P. (2011). Carbon dioxide emissions from forest biomass burning in India. Global Environmental Research, 15: 45-52.

Badia, D. and Marti, C. (2003). Plant ash and heat intensity effects on chemical and physical properties of two contrasting soils. Arid Land Research Management, 17: 23-41.

Bakhtar, A.J., Sagheb-Talebi, K., Mohajer, M.R.M. and Haidari, M. (2013). The impact of fire on the forest and plants diversity in Iranian Oak forest. International journal of Advanced Biological and Biomedical Research, 1(3): 273-284.

Boerner, R.E., Huang, J. and Hart, S.C. (2009). Impacts of fire and fire surrogate treatments on forest soil properties: A meta-analytical approach. Ecol. Appli., 19: 338-358.

Boerner, R.E.J., Brinkman, J.A. and Sutherland, E.K. (2004). Effects of fire at two frequencies on nitrogen transformation and soil chemistry in a nitrogen-enriched forest landscape. Canadian Journal of Forest Research, 34: 609-618.

Bond, W.J. and Van Wilgen, B.W. (1996). Fire and plants. London: Chapman and Hall. 272 pp.

Bormann, B.T., Homann, P.S., Darbyshire, R.L. and Morrissette, B.A. (2008). Intense forest wildfire sharply reduces mineral soil $\mathrm{C}$ and $\mathrm{N}$ : the first direct evidence. Canadian Journal of Forest Research, 38: 2771-2783.

Bradstock, R.A., Cohn, J.S., Gil, A.M., Bedward, M. and Lucas, C. (2009). Prediction of the probability of large fires in the Sydney region of south-eastern Australia using fire weather. International Journal of Wild-land Fire, 18: 932-943.

Bull, E.L. and Blumton, A.K. (1999). Effect of fuels reduction on American martens and their prey. Res. Note PNW-RN-539. Portland, OR: U.S. Department of Agriculture, Forest Service, Pacific Northwest Research Station. 9 pp.

Busse, M.D., Cochran, P.H. and Barrett, J.W. (1996). Change in Ponderosa pine site productivity following removal of understory vegetation. Soil Sci. Soc. America, 60: 1614-1621.

Busse, M.D., Simon, S.A. and Riegel, G.M. (2000). Tree-growth and under story response to low-severity prescribed burning in thinned Ponderosa Pine Forest of Central Oregon. Forest Science, 46: 258-268.

Campbell, C.D., Cameron, C.M., Bastias, B.A., Chen, C.G. and Cairney, J.W.G. (2008). Long term repeated burning in a wet sclerophyll forest reduces fungal and bacterial biomass and responses to carbon substrates. Soil Biol Biochem., 40: 2246-2252.

Casanova, J.L., Calle, A., Sanz, J., González-Alonso, F., Godammer, J.G., Li, Z. and Quin, X. (2008). Monitoring of forest fires in China through the ENVISAT-AATSR sensor. European Space Agency Special Publication, ESA SP (655 SP), Paris, France.

Certini, G. (2005). Effects of fire on properties of forest soils: a review. Oecologia, 143: 1-10.

Champion, H.G. and Seth, S.K. (1968). A revised survey of forest types in India. Government of India Publication, and New Delhi.

Chandra, S. (2005). Application of remote sensing and GIS Technology in forest fire Risk Modeling and management of forest fires: A case study in Garhwal
Himalayan Region. Geo-information for Disaster management. In: Oosterom, P., Zlatanova, S. and Fendel, E. (Eds.) 2005, XXVI, 1434p. 516 illus, ISBN: 978-3-540-24988-7.

Chatenoux, B. and Peduzzi, P. (2012). Biomass fires: preliminary estimation of ecosystems global economic losses. UNEP/GRID-Geneva. pp. 1-11.

Chen, Y., Randerson, J.T., Van der Werf, R., Morten, G.R., $\mathrm{Mu}, \quad$ M. and Kasibhatla, P.S. (2010). Nitrogen deposition in tropical forests from savanna and deforestation fires. Global Change Biology, 16: 2024 -2038 .

Choromanska, U. and DeLuca, T.H. (2001). Prescribed fire alters the impacts of wildfire on soil biochemical properties in a ponderosa pine forest. Soil Science Society of America Journal, 65: 232-238.

Connell, J.H. (1978). Diversity in tropical forests and coral reefs. Science, 1999: 1302-1310.

Dawson, T.P., Butt, N. and Miller, F. (2002). The ecology of forest fires. ASEAN Biodiversity, 1: 18-21.

DeBano, L.F. (1990). The effect of forest fire on soil properties. Symposium on management and productivity of Western-Montane forest soil. Boise, ID, USA, pp 151-156.

DeBano, L.F. (2000). The role of fire and soil heating on water repellency in Wildland environments: a review. Journal of Hydrology, 231-232: 195-206.

DeBano, L.F., Neary, D.G. and Folliott, P.F. (1998). Fire's effects on Ecosystems. John Wiley and Sons, Inc. New York.

Decocq, G., Aubert, M., Dupont, F., Alard, D., Saguez, R., Wattez-Franger, A., Foucault, B. DE, Delelis-Dusollier, A. and Bardat, J. (2004). Plant diversity in a managed temperate deciduous forest: understorey response to two silvicultural systems. J. Appl. Ecol., 41: 1065-1079.

Dezzeo, N and Chacon, N. (2006). Litter-fall and nutrient input in undisturbed and adjacent fire disturbed forests of the Gran Sabana, Southern Venezuela. Interciencia, 31(12): 894-899.

Dixon, R.K. and Turner, D.P. (1991). The global carbon cycle and climate change-responses and feedbacks from below-ground systems. Environmental Pollution, 73: 245-262.

Dixon, R.K., Brown, S., Houghton, R.A., Solomon, A.M., Trexler, M.C. and Wisniewski, J. (1994). Carbon pools and flux of global forest ecosystems. Science, 263: 185-190.

Ekinci, H. (2006). Effect of forest fire on some physical, chemical and biological properties of soil in Canakkale, Turkey. International Journal of Agriculture and Biology, 8(1): 102-106.

FAO (2007). Fire management global assessment (2006). Food and Agriculture Organization of the United Nation, 2007.

FSI (2012). Vulnerability of India's forest to fires. MOEF, Dehradun. Pp. 7.

Fynn, R.W.S., Haynes, R.J. and O'Connor, T.G. (2003). Burning causes long-term changes in soil organic matter content of South African grassland. Soil Biology and Biochemistry, 35: 677-687.

Garcia-Marco, S. and Gonzalez-Prieto, S. (2008). Short-and medium-term effects of fire and fire-fighting chemicals on soil micronutrient availability. The Science of Total Environment, 407: 297-303.

Gianoli, E., Saldana, A., Jimenez-Castillo, M. and Valladares, F. (2010). Distribution and abundance of vines along the light gradient in southern temperate rain 
forest. Journal of Vegetation Science, 21: 66-73.

Grady, K.C. and Hart, S.C. (2006). Influences of thinning, prescribed burning and wildfire on soil processes and properties in southwestern ponderosa pine forests: a retrospective study. Forest Ecology and Management, 234: 123-135.

Hiremath, A.J. and Sundaram, B. (2005). The fire-lantana cycle hypothesis in Indian forests. Conservation and Society, 3: 26-42.

Hogberg, M.N., Hogberg, P. and Myrold, D.D. (2007). Is microbial composition in boreal forest soils determined by $\mathrm{PH}, \mathrm{C} / \mathrm{N}$ ratio, the trees, or all three? Oecologia, 150 : 590-601.

Holdo, R.M., Holt, R.D. and Fryxell, J.M. (2009). Grazers, browsers, and fire influence the extent and spatial pattern of tree cover in the Serengeti. Ecological Applications, 19: 95-109.

Huff, M.H. and Smith, J.K. (2000). Fire effects on animal communities. In: Smith, J.K., ed. Wildland fire in ecosystems: effects of fire on fauna. Gen. Tech. Rep. RMRS-GTR-42-vol. 1. Fort Collins, CO: U.S. Department of Agriculture, Forest Service, Rocky Mountain Research Station; 35-42 pp.

IFFN (2002). Fire situation in India. International Forest Fire News, 26: 23-27.

Ivanauskas, N.M., Monteiro, R. and Rodrigues, R.R. (2003). Alterations following a fire in a forest community of Alto Rio Xingu. For. Ecol. Manage., 184: 239-250.

Jaiswal, R.K., Mukherjee, S., Raju, K.D. and Saxena, R. (2002). Forest fire risk zone mapping from satellite imagery and GIS. Int. J. Appl. Earth Observ. Geoinformation, 4: 1-10.

Jenkinson, D.S. and Ladd, J.N. (1981). Microbial biomass in soil, measurement and turnover. In: Paul, W.A. and Ladd, J.N. (eds.), Marcel Dekker, New York. Soil Biochemistry, 5: 415-471.

Jhariya, M.K. (2014). Effect of forest fire on microbial biomass, storage and sequestration of carbon in a tropical deciduous forest of Chhattisgarh. Ph.D. Thesis, I.G.K.V., Raipur (C.G.), pp. 259.

Jhariya, M.K., Bargali, S.S., Swamy, S.L., Kittur, B. and Bargali, K. and Pawar, G.V. (2014). Impact of forest fire on biomass and carbon storage pattern of tropical deciduous forests in Bhoramdeo Wildlife Sanctuary, Chhattisgarh. International Journal of Ecology and Environmental Sciences, 40(1): 57-74.

Jhariya, M.K. and Raj, A. (2014). Human Welfare from Biodiversity. Agrobios Newsletter, 12(9): 89-91.

Jhariya, M.K. (2013). Impact of Fires on Forest Ecosystem: Vegetational Response to Forest Fire. Lap Lambert Academic Publishing. Heinrich-Bocking-Str. 6-8, 66121, Saarbrucken, Germany. 104 pp.

Jhariya, M.K., Bargali, S.S., Swamy, S.L. and Oraon, P.R. (2013). Herbaceous diversity in proposed mining area of Rowghat in Narayanpur District of Chhattisgarh, India. Journal of Plant Development Sciences, 5(4): 385 $-393$

Jhariya, M.K. and Oraon, P.R. (2012a). Regeneration Status and Species Diversity along the Fire Gradients in Tropical Deciduous Forest of Chhattisgarh. Journal of Plant Development Sciences, 4(1): 49-54.

Jhariya, M.K. and Oraon, P.R. (2012b). Analysis of herbaceous diversity in fire affected areas of Bhoramdeo Wildlife Sanctuary, Chhattisgarh. The Bioscan, 7(2): 325-330.

Jhariya, M.K. and Oraon, P.R. (2012c). Lianas and Shrubs
Regeneration, Distribution Pattern and Diversity in Tropical Forest Ecosystem of Chhattisgarh. The Bioscan, 7(3): 377-382.

Jhariya, M.K., Bargali, S.S., Swamy, S.L. and Kittur, B. (2012). Vegetational Structure, Diversity and Fuel Loads in Fire Affected areas of Tropical Dry Deciduous Forests in Chhattisgarh. Vegetos, 25(1): 210-224.

Jhariya, M.K. (2011). Impact of forest fire on biodiversity conservation. Int. Res. J. Lab to Land, 3(12): 555-560.

Jhariya, M.K. (2010). Analysis of vegetational structure, diversity and fuel load in fire affected areas of tropical dry deciduous forests in Chhattisgarh. M.Sc. Thesis, I.G.K.V., Raipur (C.G.), pp. 86.

Johnson, D.W. (1992). Effects of forest management on soil carbon storage. Water, Air, and Soil Pollution, 64: 83-120.

Johnson, D.W. and Curtis, P.S. (2001). Effects of forest management on soil $\mathrm{C}$ and $\mathrm{N}$ storage: meta-analysis. Forest Ecology and Management, 140: 227-238.

Joshi, N.R., Tewari, A. and Chand, D.B. (2013). Impacts of forest fire and aspects on phytosociology, tree biomass and carbon stock in oak and pine mixed forests of Kumaun central Himalaya, India. Researcher, 5(3): 1-8.

Kauffman, J.B., Steele, M.D., Cummings, D.L. and Jaramillo, V.J. (2003). Biomass dynamics associated with deforestation, fire, and, conversions to cattle pasture in a Mexican tropical dry forest. Forest Ecology and Management, 176: 1-12.

Keith, R.P., Thomas, T.V., Tania, L.S. and Rosemary, L.S. (2010). Understory vegetation indicates historic fire regimes in ponderosa pine-dominated ecosystems in the Colorado Front Range. Journal of Vegetation Science, 21: 488-499.

Khandekar, M.L., Murty, T.S., Scott, D. and Baird, W. (2000). The $1997 \mathrm{El} \mathrm{Nino,} \mathrm{Indonesian} \mathrm{forest} \mathrm{fires} \mathrm{and}$ the Malaysian smoke problem: a deadly combination of natural and man-made hazard. Natural Hazards, 21(2-3): 131-144.

Kirkpatrick, C., Conway, C.J. and Jones, P.B. (2006). Distribution and relative abundance of forest birds in relation to burn severity in southeastern Arizona. Journal of Wildlife Management, 70(4): 1005-1012.

Kittur, B., Swamy, S.L., Bargali, S.S. and Jhariya, M.K. (2014a). Wildland Fires and Moist Deciduous Forests of Chhattisgarh, India: Divergent Component Assessment. Journal of Forestry Research, (DOI) 10.1007/s11676 -014-0471-0. pp. 1-10.

Kittur, B., Jhariya, M.K. and Lal, C. (2014b). Is the forest fire can affect the regeneration and species diversity. Ecology, Environment and Conservation, 20(3): 989-994.

Kittur, B. and Jhariya, M.K. (2012). Quantification of fuel loads in fire affected areas of tropical moist deciduous forests of Achanakmar-Amarkantak Biosphere Reserve. Journal of Plant Development Sciences, 4(2): 333-335.

Klock, G.O. and Grier, C.C. (1979). Effects of fire on the long-term maintenance of forest productivity. In Proc. Conf. on Forest Fertilization, Sept. 25-27, 1979. S.P. Gessel, R.M. Kenady, and W.A. Atkinson (editors). Seattle, Wash., pp. 247-250.

Knoepp, J.D., Vose, J.M. and Swank, W.T. (2004). Long-term soil response to site preparation burning in the Southern Appalachians. Forest Science, 50: 540-550.

Kodandapani, N., Cochrane, M.A. and Sukumar, R. (2008). A comparative analysis of spatial, temporal, and ecological characteristics of forest fires in a seasonally dry tropical ecosystem in the Western Ghats, India. 
Forest Ecology and Management, 256: 607-617.

Krishna, P.H. and Reddy, C.S. (2012). Assessment of increasing threat of forest fires in Rajasthan, India using multi-temporal remote sensing data (2005-2010). Current Science, 102(9): 1288-1297.

Kumar, R. and Thakur, V. (2008). Effect of forest fire on trees, shrubs and regeneration behavior in Chir-pine forest in northern aspects under Solan forest division. Himachal Pradesh. Indian Journal of Forestry, 31(1): 19-27.

Lal, R. (2004). Soil carbon sequestration to mitigate climate change. Geoderma, 123: 1-22.

Laughlin, D.C., Bakker, J.D., Stoddard, M.T., Daniels, M.L. and Springer, J.D. (2004). Toward reference conditions: wildfire effects on flora in an old-growth Ponderosa Pine forest. Ecol. Manage., 199: 137-152.

Laurance, W.F., Perez-Salicrup, D., Delamonica, P., Fearnside, P.M., D'angelo, S., Jerozolinski, A., Pohl, L. and Lovejoy, T.E. (2001). Rain forest fragmentation and the structure of Amazonian liana communities. Ecology, 82: 105-116.

Leckie, S.E., Prescott, C.E. and Grayston, S.J. (2004). Forest floor microbial community response to tree species and fertilization of regenerating coniferous forests. Canadian Journal of Forest Research, 34: 1426-1435.

Leone, V., Lovreglio, R., Martín, M.P., Martínez, J. and Vilar, L. (2009). Human factors of fire occurrence in the Mediterranean. Pages 149-170 in: E. Chuvieco, editor. 2009. Earth observation of wild-land fires in Mediterranean ecosystems. Springer-Verlag, Heidelberg, Germany. doi: 10.1007/978-3-642-01754-4_11.

Letey, J. (2001). Causes and consequences of fire-induced soil water repellency. Hydrological Processes, 15(15): 2867-2875.

Littell, J., McKenzie, D., Peterson, D.L. and Westerling, A.L. (2009). Climate and wildfire area burned in western US ecoprovinces, 1916-2003. Ecological Applications, 19: $1003-1021$

Liu, W., Xu, W., Han, Y., Wang, C. and Wan, S. (2007). Responses of microbial biomass and respiration of soil to topography, burning, and nitrogen fertilization in a temperate steppe. Biology and Fertility of Soil, 44: 259-268.

Lyon, L.J., Telfer, E.S. and Schreiner, D.S. (2000b). Direct effects of fire and animal responses. In: Smith, J.K., ed. Wild land fire in ecosystems: effects of fire on fauna. Gen. Tech. Rep. RMRS-GTR-42-vol. 1. Ogden, UT: U.S. Department of Agriculture, Forest Service, Rocky Mountain Research Station; 17-23 pp.

Mabuhay, J.A., Nakagoshi, N. and Horikoshi, T. (2003). Microbial biomass abundance after forest fire in pine forests in Japan. Ecological Research, 18: 431-441.

Mallik, A.U. (2003). Conifer regeneration problems in boreal and temperate forests with ericaceous understory: role of disturbance, seedbed limitation, and keystone species change. Crit. Rev. Plant Sci., 22: 341-366.

Menon, S., Hansen, J., Nazarenko, L. and Luo, Y.F. (2002). Climate effects of black carbon aerosols in China and India. Science, 297: 2250-2253.

Miller, M. (2000). Wildland fire in ecosystems, effects of fire on flora, RMRS-GTR-42. Vol. 2. pp. 275.

Mishra, R.K., Upadhyay, V.P. and Mohanty, R.C. (2008). Vegetation Ecology of the Simplipal Biosphere Reserve, Orissa India. Applied Ecology and Environment Research, 6(2): 89-99.

Mol, T. and Kucukosmanoglu, A. (1997). Forest fires in
Turkey. In Proc. XI. World Forestry Congress, Antalya, Turkey.

Moretti, M., Zanini, M. and Conedera, M. (2002). Faunistic and floristic post-fire succession in southern Switzerland: an integrated analysis with regard to fire frequency and time since the last fire. Forest Fire Research and Wildland Fire Safety, Viegas (ed.), ISBN 90-77017-72-0.

Murphy, J.D., Johnson, D.W., Walker, W.W., Miller, R.F., Carroll, E.F. and Blank, R.R. (2006). Wildfire effects on soil nutrients and leaching in a Tahoe Basin Watershed. Journal of Environmental Quality, 35: 479-489.

Murphy, P.G. and Lugo, A.E. (1986a). Ecology of tropical dry forest. Annual Review of Ecology and Systematic, 17: $67-68$.

Mustafa, Y. (2009). Forest Fires. 1. Orman yanginlari ile mucadeles sempozyumu, 7-10 January 2009 Antalya, Turkey; 129-130 pp.

Myers, R.L. (1990). Scrub and high pine. In: Myers, R.L. and Ewel, J.J., eds. Ecosystems of Florida. Orlando, FL: University of Central Florida Press; 150-193 pp.

Nabatte, P. and Nyombi, K. (2013). Effects of pine plantation surface fires on soil chemical properties in Uganda. Research Journal of Agriculture and Forestry Sciences, 1(7): 10-14.

Nardoto, G.B. and Bustamante, M.M.D.C. (2003). Effects of fire on soil nitrogen dynamics and microbial biomass in Savannas of Central Brazil. Pesq. Agropec. Bras., 38 (8): 955-962.

Narendran, K., Murthy, I.K., Suresh, H.S., Dattaraja, H.S., Ravindranath, N.H. and Sukumar, R. (2001). Non-timber forest product extraction, utilization and valuation: a case study from the Nilgiri Biosphere Reserve, Southern India. Economic Botany, 55: 528-538.

Neary, D.G., Klopatek, C.C., DeBano, L.F. and Ffolliott, P.F. (1999). Fire effects on belowground sustainability: a review and synthesis. Forest Ecology and Management, 122: $51-71$.

Neary, D.G., Ryan, K.C. and DeBano, L.F. (2005). Wildland fire in ecosystem: effects of fire on soils and water. Gen. Tech. Rep. RMRS-GTR-42-vol.4. Ogden, UT: U.S. Department of Agriculture, Forest Service, Rocky Mountain Research Station; 250 pp.

Neff, J., Harden, J. and Gleixner, G. (2005). Fire effects on soil organic matter content, composition, and nutrients in boreal interior Alaska. Canadian Journal of Forest Research, 35: 2178-2187.

Neyisci, T. (1985). Antalya doyran yoresi kizilcam (Pinus brutia Ten.) ormanlarinda yanginlarin tarihsel etkileri [Historical role of fire on red pine (Pinus brutia Ten.) forests of Antalya Doyran region], Ormancilik Arastirma Enstitusu Yayinlari, Teknik Rapor Seri No. 29; 67-91 pp.

Niwa, C.G. and Peck, R.W. (2002). Influence of prescribed fire on carabid beetle (Carabidae) and spider (Araneae) assemblages in forest litter in southwestern Oregon. Environmental Entomology, 31(5): 785-796.

Ojima, D.S., Schimel, D.S., Parton, W.J. and Owensby, C.E. (1994). Long and short term effects of fire on nitrogen cycling in tall-grass prairie. Biogeochemistry, 24: 67-84.

Otsuka, S., Sudiana, I.M., Komori, A., Isobe, K., Deguchi, S., Nishiyama, M., Shimizu, H. and Senoo, K. (2008). Community structure of soil bacteria in a tropical rainforest several years after fire. Microbes and Environments, 23(1): 49-56. 
Payette, S. and Delwaide, A. (2003). Shift of conifer boreal forest to lichen-heath parkland caused by successive stand disturbances. Ecosystems, 6: 540-550.

Perez-Salicrup, D.R., Sork, V.L. and Putz, F.E. (2001). Liana and trees in a liana forest in Amazonian Bolivia. Biotropica, 33: 34-47.

Pilliod, D.S., Bury R.B., Hyde, E.J., Pearl, C.A. and Corn, P.S. (2003). Fire and amphibians in North America. Forest Ecology and Management, 178: 163-181.

Putz, F.E. (1983). Liana biomass and leaf area of a "tierra firme" forest in the Rio Negro basin, Venezuela. Biotropica, 15: 185-189

Raj, A. and Jhariya, M.K. (2014). Impact of forest fire on the ecosystem and environment. Reader shelf, 10(8): 4-6.

Reinking, D.L. (2005). Fire regimes and avian responses in the central tall-grass prairie. Studies in Avian Biology, 30: 116-126.

Rocha, W., Metcalfe, D.B., Doughty, C.E., Brando, P., Silverio, D., Halladay, K., Nepstad, D.C., Balch, J.K. and Malhi, Y. (2013). Ecosystem productivity and carbon cycling in intact and annually burnt forest at the dry southern limit of the Amazon rainforest (Mato Grosso, Brazil). Plant Ecology and Diversity, Pp. 1-16. DOI: 10.1080/17550874.2013.798368.

Rodgers, W.A., Bennet, S.S.R. and Sawakar, W.B. (1986). Fire and vegetation structure in Sal forests, Dehradun, India. Tropical Ecology, 27(1): 49-61.

Rodriguez, A., Duran, J., Fernandez-Palacios, J.M. and Gallardo, A. (2009). Short-term wildfire effects on the spatial pattern and scale of labile organic-N and inorganic-N and $\mathrm{P}$ pools. Forest Ecology and Management, 257: 739-746.

Rutigliano, F.A., De Marco, A., D' Ascoli, R., Castaldi, S., Gentile, A. and De Santo, A.V. (2007). Impact of fire on fungal abundance and microbial efficiency in $\mathrm{C}$ assimilation and mineralization in a Mediterranean maquis soil. Biology and Fertility of Soils, 4: 377-381.

Saha, S. (2002). Anthropogenic fire regime in a central India deciduous forest. Current Science, 82: 1144-1147.

Saha, S. and Howe, H.F. (2003). Species composition and fire in a dry deciduous forest. Ecology, 84(12): 3118-3123.

Sahu, P.K., Sagar, R. and Singh, J.S. (2008). Tropical forest structure and diversity in relation to altitude and disturbance in a Biosphere Reserve in central India. Applied Vegetation Science, 11: 461-470.

Schnitzer, S.A. and Bongers, F. (2002). The ecology of lianas and their role in forests. Trends in Ecology and Evolution, 17: 223-230.

Schnitzer, S.A. and Bongers, F. (2011). Increasing liana abundance and biomass in tropical forests: emerging patterns and putative mechanisms. Ecology Letters, 1-10.

Schnitzer, S.A., Bongers, F. and Powers, J. (2012). Understanding the increase in lianas in neotropical forests. In: Symposium (12) "Ecology, Evolution and Sustainable use of Tropical Biodiversity", 18-22 June, 2012. Bonito Convention Center, Brazil.

Sharma, C.M., Gairola, S., Baduni, N.P., Ghildiyal, S.K. and Suyal, S. (2011). Variation in carbon stocks on different slope aspects in seven major forest types of temperate region of Garhwal Himalaya, India. J. Biosci. 36(4): 701-708.

Sheuyange, A., Oba, G. and Weladji, R.B. (2005). Effects of anthropogenic fire history on savanna vegetation in northeastern Namibia. Journal of Environmental Management, 75: 189-198.
Solomon, S., Qin Manning, D.M., Chen, Z., Marquis, M., Averyt, K.B., Tignor, M. and Miller, H.L. (2007). The physical science basis-contribution of working group I to the fourth assessment report of the inter-governmental panel on climate change, Cambridge Univ. Press, Cambridge, U.K., New York, USA.

Sperry, J.H., George, T.L. and Zack, S. (2008). Ecological factors affecting response of dark-eyed juncos to prescribed burning. The Wilson Journal of Ornithology, 120(1): 131-138.

SSSA (2001). Glossary of Soil Science Terms. Soil science society of America. Madison, USA.

Sun, Y., Wu, J., Shao, Y., Zhou, L., Mai, B., Lin, Y. and Fu, S. (2011). Responses of soil microbial communities to prescribed burning in two paired vegetation sites in southern China. Ecological Research, 26: 669-677.

Swallow, M., Quideau, S.A., Mackenzie, M.D. and Kishchuk, B.E. (2009). Microbial community structure and function: the effect of silvicultural burning and topographic variability in northern Alberta. Soil Biology \& Biochemistry, 41: 770-777.

Thornley, J.H.M. and Cannell, M.G.R. (2004). Long-term effects of fire frequency on carbon storage and productivity of boreal forests: a modeling study. Tree Physiology, 24: 765-773.

Van der Werf, G.R., Randerson, J.T., Collatz, G.J. and Giglio, L. (2003). Carbon emissions from fires in tropical and subtropical ecosystems. Global Change Biology, 9: 547-562.

Vargas, R., Allen, M.F. and Allen, E.B. (2008). Biomass and carbon accumulation in a fire chronosequence of a seasonally dry tropical forest. Global Change Biology, 14: 109-124.

Wade, D.D., Brock, B.L., Brose, P., Grace, J.B., Hoch, G.A. and Patterson, W.A. (2000). Fire in eastern ecosystems. In: Brown, J.K. and Smith, J.K., eds. Wildland fire in ecosystems: effects of fire on flora. Gen. Tech. Rep. RMRS-GTR-42-vol. 2. Fort Collins, CO: U.S. Department of Agriculture, Forest Service, Rocky Mountain Research Station; 53-96 pp.

Waldrop, M.P. and Harden, J.W. (2008). Interactive effects of wildfire and permafrost on microbial communities and soil processes in an Alaskan black spruce forest. Global Change Biology, 14: 2591-2602.

Wang, J. and Christopher, S.A. (2006). Mesoscale modeling of Central America smoke transport to the United States: 2. Smoke radiative impact on regional surface energy budget and boundary layer evolution. Journal of Geophysical Research-Atmospheres, 111 pp. D14S92, doi: 10.1029/2005JD006720.

Wang, Q., Zhong, M. and Wang, S. (2012). Meta-analysis on the response of microbial biomass dissolved organic matter, respiration, and $\mathrm{N}$ mineralization in mineral soil to fire in forest ecosystems. Forest Ecology and Management, 271: 91-97.

Wang, Y., Flannigan, M. and Anderson, K. (2010). Correlations between forest fires in British Columbia, Canada, and sea surface temperature of the Pacific Ocean. Ecological Modeling, 221: 122-129. doi: 10.1016 /j.ecolmodel.2008.12.007.

Waring, R.H. and Running, S.W. (1998). Forest Ecosystems: Analysis at Multiple Scales. Academic Press, San Diego.

Wienk, C.L., Sieg, C.H. and McPherson, G.R. (2004). Evaluating the role of cutting treatments, fire and soil seed banks in 
an experimental framework in Ponderosa Pine Forest of the Black Hills. South Dakota. Forest Ecol. Manage., 192: 375-393.

Wilson, C.A., Mitchell, R.J., Boring, L.R. and Hendricks, J.J.

(2002). Soil nitrogen dynamics in a fire maintained forest ecosystem-results over a 3-year burn interval. Soil
Biology and Biochemistry, 34: 679-689.

Zhang, Y.M., Wu, N., Zhou, G.Y. and Bao, W.K. (2005). Change in enzyme activities of spruce (Picea balfouriana) forest soil as related to burning in the eastern Qinghai-Tibetan Plateau. Applied Soil Ecology, 30: 215-225. 